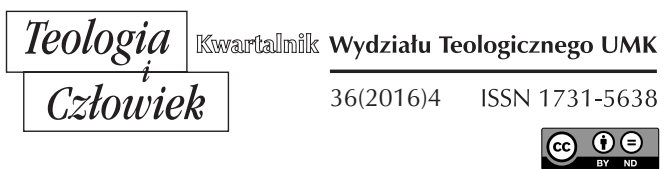

RENATA ALEKSANDROWICZ

EWA REPUCHO*

WROCŁAW

\title{
TEKST NATCHNIONY W OBLICZU NOWYCH TECHNOLOGII. BIBLIA TYSIĄCLECIA W APLIKACJI NA TELEFON. PERSPEKTYWA ODBIORCY
}

DOI: http://dx.doi.org/10.12775/TiCz.2016.049

Czytanie dokonuje się w kontekście innych środków komunikowania społecznego,

które nigdy wcześniej w takim stopniu nie wplywały na samo funkcjonowanie i sposób użytkowania pisma, a w konsekwencji na przeobrażenia mentalności odbiorców.

Irena Socha

\section{WSTĘP}

W publikowanym wcześniej artykule pt. Tekst natchniony w obliczu nowych technologii. Biblia Tysiaclecia w aplikacji na telefon. Perspektywa $w y d a w c y^{1}$, przedstawiłyśmy zmieniające się formy prezentowania i udo-

* Dr Renata Aleksandrowicz, dr Ewa Repucho - Instytut Informacji Naukowej i Bibliotekoznawstwa Uniwersytetu Wrocławskiego (renata.aleksandrowicz@uwr.edu.pl; ewa.repucho@uwr.edu.pl).

1 Tekst natchniony w obliczu nowych technologii. Biblia Tysiaclecia $w$ aplikacji na telefon. Perspektywa wydawcy, „Teologia i Człowiek” niniejszy numer, s. 149-166. 
stępniania Pisma św., a także ich zależność od mód i prądów estetycznych, oraz możliwości technologicznych. Przejście Biblii w przestrzeń cyfrową stwarza dodatkowy obszar dla badaczy czytelnictwa, otwiera nowe pola badawcze odnoszące się do poznania wpływu współczesnych środków przekazu na praktyki lekturowe czytelników Księgi Ksiąg. W niniejszym tekście, przedmiotem naszych rozważań będą zachowania czytelników Pisma św., związane $\mathrm{z}$ użytkowaniem jego wersji mobilnej. W artykule przedstawimy miejsca i okoliczności korzystania z aplikacji Pismo Święte, wskażemy - z perspektywy odbiorcy - jej wady, zalety i najczęściej wykorzystywane funkcje, oraz opiszemy zachowania komunikacyjne użytkowników związane ze współedycją Biblii na telefon. W podsumowaniu spróbujemy wskazać przełamywanie granic lub przenikanie się obszarów na styku odbioru tradycyjnego kodeksu i użytkowania aplikacji.

Głównym celem naszych badań było poznanie i opisanie wskazanych wyżej zachowań odbiorczych. Aby zrealizować cel naukowy, przeprowadziłyśmy analizę opinii zamieszczanych na profilu Pismo Święte. Oprogramowanie portalu społecznościowego Facebook oraz komentarzy, jakie na stronie www.pismo.swiete.pl, umieścili jego użytkownicy od listopada 2014 do stycznia $2016 .{ }^{2}$ Równolegle zrealizowałyśmy badania ankietowe wśród członków katolickich wspólnot religijnych działających na terenie Wrocławia (m.in. Equipes Notre-Dame ruch duchowości małżeńskiej, Koinonia Św. Jan Chrzciciel). Był to celowy dobór próby ${ }^{3}$, aby dotrzeć do osób, które potencjalnie często mają potrzebę lektury, kontemplowania i użytkowania Księgi Ksiąg. Sondaż był swego rodzaju rekonesansem, pilotażem $\mathrm{i}$ - w połączeniu $\mathrm{z}$ opiniami internautów - ułatwił wskazanie podstawowych tendencji w zachowaniach współczesnych czytelników/użytkowników Pisma św., korzystających jednocześnie z aplikacji mobilnej. Ankietę przeprowadzono wśród 105 respondentów. Była to grupa silnie sfeminizowa na ( $72 \%$ kobiet, $28 \%$ mężczyzn) i stosunkowo młoda, przeważały bowiem osoby do 40 . a przede wszystkim do 30. roku życia (wykres 1$)^{4}$.

${ }^{2} \mathrm{~W}$ ciągu analizowanych 16 miesięcy pojawiło się tam blisko 2500 opinii.

3 E. Babbie, Badania społeczne w praktyce, Warszawa 2006, s. 205.

${ }^{4}$ Wykresy w niniejszym tekście prezentują wyniki własnych badań ankietowych 


\section{Wykres 1. Wiek respondentów}

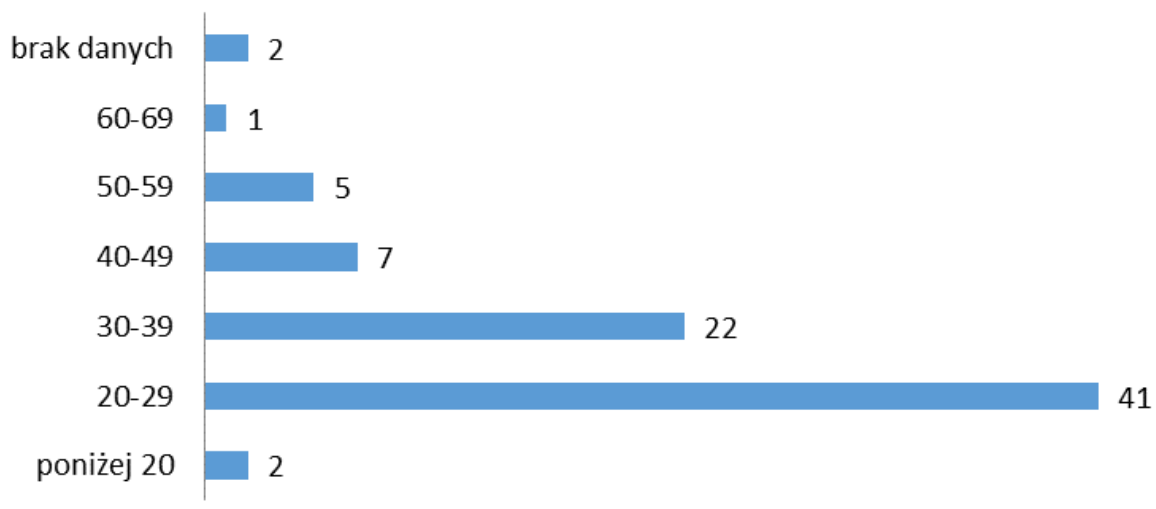

\section{UŻYTKOWNICY}

Omawianą aplikację posiadała i użytkowała zdecydowana większość badanych (84\%), jej dość częstymi odbiorcami byli również członkowie rodzin respondentów (57\%). Nośnik, który „zawsze był pod ręką” sprzyjał niewątpliwie dużej częstotliwości użytkowania, bowiem wśród korzystających z aplikacji prawie $2 / 3$ stanowili aktywni czytelnicy sięgający do niej przynajmniej raz dziennie. Niemała grupa (co czwarty użytkownik) deklarowała lekturę Pisma świętego na telefon 2-3 razy w tygodniu (wykres 2).

Wykres 2. Częstotliwość korzystania z aplikacji

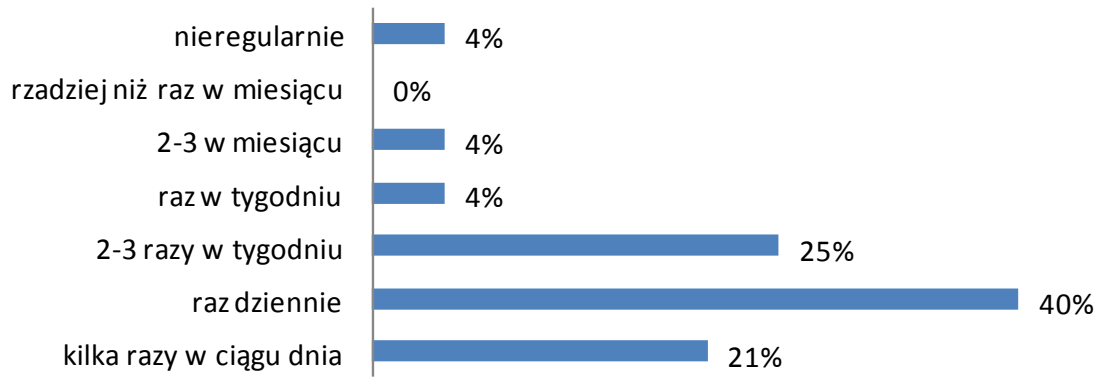


Potencjał kolekcji stworzonej na potrzeby aplikacji jest nie do przecenienia, wydawało się więc, że badani będą korzystać głównie z tych funkcji, jakich nie dawała im wersja tradycyjna. Niewątpliwie czerpano pełną garścią z możliwości Biblii mobilnej i wielokrotnie traktowano aplikację użytkowo do szybkiego wyszukiwania czy tworzenia zakładek. Jednak największą popularnością cieszyły się czytania na każdy dzień, biblia, modlitewnik i brewiarz czyli zwyczajowe użytkowanie tradycyjnej wersji papierowej związane $\mathrm{z}$ modlitwą osobistą lub wspólnotową (wykres 3).

Wykres 3. Najczęściej wykorzystywane funkcje aplikacji

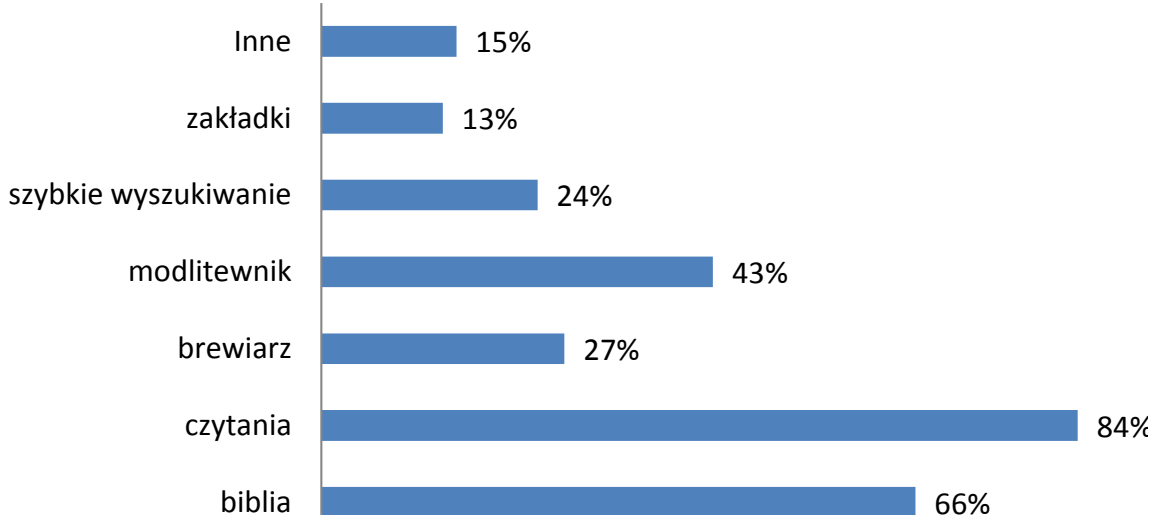

\section{MIEJSCA I OKOLICZNOŚCl}

Powszechna dostępność i poręczność telefonu wpływały niewątpliwie na rozmaitość miejsc, w jakich korzystano z aplikacji. Wprawdzie dla większości respondentów dom był obszarem, w którym zazwyczaj podejmowali lekturę, wszelako bardzo chętnie zaglądano też do Biblii na telefon podróżując, przemieszczając się z miejsca na miejsce, zazwyczaj w drodze do pracy bądź na uczelnię. Oprócz tego, co trzeci użytkownik korzystał $\mathrm{z}$ aplikacji $\mathrm{w}$ rozmaitych miejscach oczekiwania, takich jak przystanki, poczekalnie, urzędy. Natomiast grupa najwierniejszych czytelników przyznawała, że czyta absolutnie wszędzie, niektórzy nawet w pracy (wykres 4). 
Wykres 4. Miejsce korzystania z aplikacji

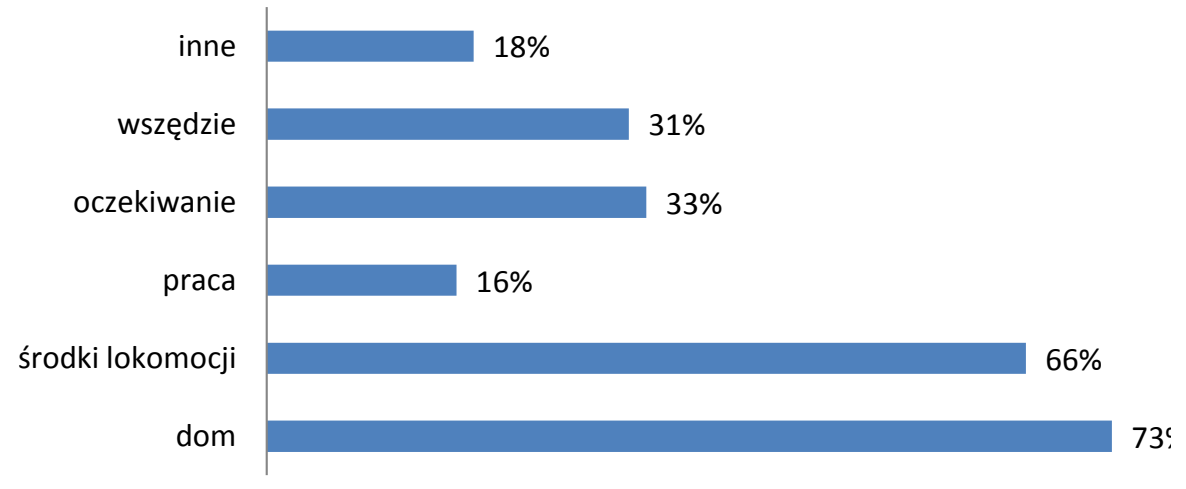

Dość tradycyjne z kolei wydały się okoliczności, w których sięgano po aplikację. Respondenci wykorzystywali bowiem wersję mobilną do indywidualnej modlitwy osobistej, jednocześnie posiłkowano się telefonem podczas wspólnotowych spotkań rodzinnych lub religijnych. Znalazła się też grupa, dla której telefon z Pismem św. stanowił ratunek w trudnych sytuacjach życiowych. Natomiast blisko połowa użytkowników podejmowała lekturę bez reguły, w wielu najrozmaitszych okolicznościach i sytuacjach życiowych (wykres 5).

Wykres 5. Okoliczności korzystania z aplikacji

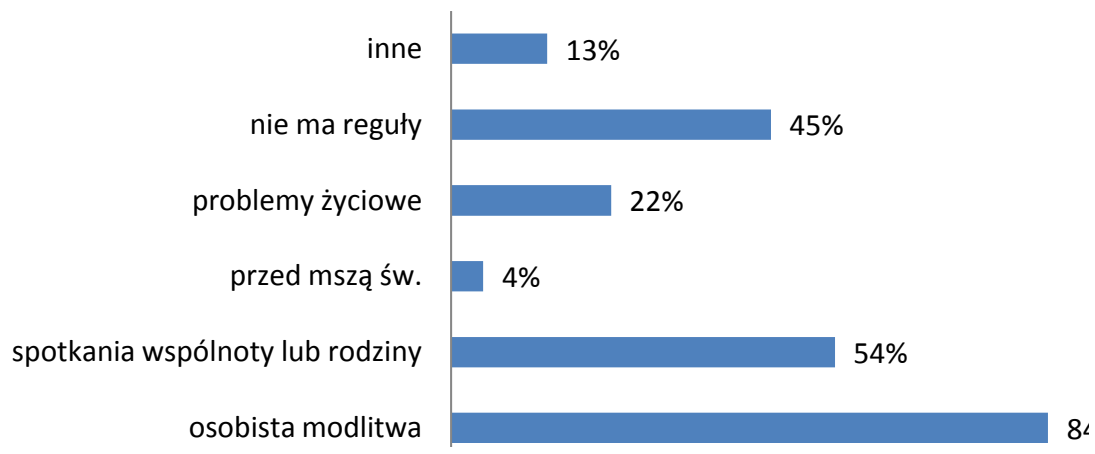

Interesujące wydało się sprawdzenie, czy pomimo łatwego dostępu do wersji mobilnej, jej użytkownicy stawiają sobie jakieś ograni- 
czenia , czy są miejsca/sytuacje, w których respondenci mają opory żeby korzystać z Biblii na telefon. Okazało się, że decydowały o tym różne aspekty, a w wielu przypadkach coś co stanowiło barierę dla jednych, było walorem dla innych.

Ze względu na powszedni i zbyt uniwersalny - zdaniem niektórych - charakter nośnika, niezbyt chętnie podejmowano lekturę w miejscach, w których nie wolno bądź nie należy korzystać z telefonu. Dotyczyło to zwłaszcza miejsc kultu, świątyń, np.: podczas rekolekcji czy mszy: $W$ kościele, mimo że to Boże Słowo, uważam, że to brak szacunku. Niekiedy opory te wynikały z obawy przed opinią otoczenia, np. Często otwierając [aplikację w telefonie - przyp. autorek] w Kościele podczas adoracji, starsze osoby krzywo na mnie patrza.

Ze względu na charakter treści, niektórzy respondenci mieli obiekcje, aby czytać Biblię mobilną w miejscach publicznych i rozrywkowych. Zwracano chociażby uwagę, że są to miejsca, w których trudno się skoncentrować, np.:

Pomimo łatwego dostępu do Pisma św. dzięki aplikacji, w miejscach takich, jak centrum handlowe czy basen, miałabym opory aby czytać Pismo, ponieważ sa to miejsca gwarne i pelne ludzi. Kiedy czytam Pismo potrzebuje wyciszenia i koncentracji. Aplikacja stwarza świetne warunki, aby czytać Pismo na łonie natury.

Nierzadko atencja dla samej czynności, jaką jest lektura Biblii, wymagała miejsc o innym charakterze, np. Dla mnie czytanie Pisma św. jest modlitwa, dlatego robię to $w$ domu, bądź w kościele, $w$ zaciszu swego serca. W takich przypadkach radzono sobie niekiedy przyjmując swego rodzaju kryterium funkcjonalne: Jeżeli ma być to forma modlitwy, to tak [mam opory aby czytać wszędzie - przyp. autorek], ale jeśli chcę tylko coś sprawdzić, to nie. Niektórych użytkowników wersji mobilnej zniechęcała też sama obecność innych ludzi, choćby współpasażerów podróży. Toteż jako niesprzyjające lekturze wymieniano np. Miejsca, w których wiem, że ktoś może widzieć ekran mojego telefonu i tym samym nieco ograniczać osobistość korzystania $z$ aplikacji np. $w$ dużym tłoku w komunikacji miejskiej.

Wypowiedzi respondentów wskazywały jednakże na fakt stopniowego przyzwyczajania się do elektronicznego nośnika i przystosowania do nowych, niekiedy niespodziewanych miejsc czy okoliczności, np. Czasem 
pojawiaja się takie opory, ale $z$ dnia na dzień jest ich coraz mniej. Nieliczne osoby utrzymywały, że wstrzymują się przed lekturą jedynie w toalecie. Generalnie, zdecydowana większość użytkowników (87\%) stwierdzała, że nie ma żadnych obiekcji ani skrupułów, żeby korzystać z możliwości aplikacji wszędzie, uznając niejako że tekst/treść „uświęca” miejsce i okoliczności. Mało tego, dla wielu respondentów, możliwość czytania Pisma św. w różnych sytuacjach i w otoczeniu różnych ludzi stanowiło rodzaj świadectwa np. Nie [mam oporów - przyp. autorek], ponieważ to moja wiara i sie tego nie wstydzę.

Użytkownicy aplikacji, w ankietach i na stronach internetowych, wyrażali swoje opinie wskazując zarówno na zalety, jak i niedoskonałości wersji na telefon. Należy przy tym zauważyć, że cechy/czynniki wskazywane przez jednych jako ograniczenia, przez innych były niejednokrotnie określane jako walory otwierające nowe perspektywy użytkowania.

\section{ZALETY WERSJI MOBILNEJ}

Zdecydowanie częściej wymieniano zalety wersji mobilnej i niemal zachwycano się całą gamą jej możliwości. Wśród plusów aplikacji najczęściej wskazywano: ciągły i wygodny dostęp, zniesienie ograniczeń wersji tradycyjnej, nowe możliwości i sposoby korzystania.

1. Jako jeden $z$ najważniejszych walorów uznano szerokie możliwości niemal permanentnego dostępu do Słowa, np.: mogę czytać $w$ każdym miejscu i dowolnym czasie, $w$ pociagu, w kajaku. Podkreślano przy tym, że można $\mathrm{z}$ aplikacji korzystać $\mathrm{w}$ rozmaitych okolicznościach, $n p$. $w$ zatłoczonym autobusie; czasem zupełnie niezaplanowanych, kiedy znajduje się odrobina czasu nieprzewidzianego. Tak więc lektura Pisma możliwa jest w sytuacjach nietypowych, np.: Przy małych dzieciaczkach niezbędnik mamy - szybki dostęp, gdy tylko jest choć chwila (w poczekalni u lekarza, kolejce sklepowej, nocy przy karmieniu), a nawet w momentach dość niekonwencjonalnych, np.: podczas karmienia dziecka piersia:) bo ciężko trzymać wtedy Biblię w tradycyjnej formie.

2. Respondenci wielokrotnie podkreślali, że dużą zaletą aplikacji na telefon jest zniesienie ograniczeń wersji tradycyjnej. Zwracano uwagę na wygodę, bowiem dzięki wielofunkcyjności telefonu 
komórkowego praktycznie można nie rozstawać się z nośnikiem, np. Zazwyczaj mam przy sobie telefon, nie jest to wielka „cegła”, zawsze jest pod ręką, można sięgnąc do niego $w$ każdej chwili. Chwalono sobie możliwość lektury po ciemku lub bez dostępu do prądu, np. Nie potrzeba światła, moge czytać gdy w pokoju jest ciemno. Nie bez znaczenia była też możliwość wykorzystania każdej wolnej chwili, np.: Super! Szczególnie przy ograniczonym czasie na skupienie; a nawet walor ograniczenia dolegliwości psychofizycznych, np.: Mi osobiście łatwiej czytać z telefonu, bo $z$ książki w autobusie czytać nie moge ze względu na odzywajaca sie wówczas chorobę lokomocyjna.

3. Użytkownicy zwracali oczywiście uwagę na nowe możliwości i sposoby korzystania z wersji mobilnej. Ceniono sobie łatwość wyszukiwania potrzebnych fragmentów i otwierania stron $z$ pożądanym tekstem. Nie bez znaczenia była wygodna nawigacja, np.: znacznie łatwiej poruszać się po przypisach, odnośnikach niż $w$ wersji książkowej. Dla respondentów ważna była też możliwość zaznaczenia fragmentu $i$ wracania do niego, a także dostosowania stopnia pisma do indywidualnych potrzeb.

\section{WADY WERSJI MOBILNEJ}

Mimo wielu dobrych stron rozwiązania mobilnego, przekraczanie granicy Księgi Ksiąg niosło za sobą różne ograniczenia, a nawet bywało dotkliwe. Wśród najczęściej wskazywanych problemów, wymieniano: ograniczenia technologiczne, bariery psychologiczne / psychofizyczne, naruszenie sfery sacrum i trudność zerwania $\mathrm{z}$ formą tradycyjną.

1. Ograniczenia technologiczne - mimo młodego wieku użytkowników - okazały się jedną z częściej wymienianych barier w korzystaniu z wersji mobilnej. Wskazywano na niedostateczną wielkość ekranu, utrudniającą swobodną "pełną” lekturę, np.: Trzeba się przyzwyczaić do małego ekranu i czytania nieco innego, niż w formie papierowej. Użytkownikom przeszkadzała zależność od sprawnego urządzenia i dostępu do prądu, np. problem, jak się telefon rozładuje. Zwracano uwagę na brak możliwości zrobienia osobistych notatek, podkreśleń czy ograniczenia zakładek, np. w zakładkach można zapisywać tylko po jednym wersecie. Nie 
bez znaczenia był też utrudniony dostęp do komentarzy i odnośników, oraz niemożność „wylosowania” fragmentu.

2. Zarówno nieco starsi, jak i młodsi użytkownicy wskazywali na bariery psychologiczne i psychofizyczne jako utrudniające korzystanie $\mathrm{z}$ aplikacji. Wymieniano chociażby problemy $\mathrm{z}$ koncentracją i skupieniem podczas czytania $\mathrm{z}$ ekranu, np. czytajac na papierze łatwiej jest medytować, wyciszyć się. Lektura w telefonie nie sprzyjała też pełnej uwadze i przyswajaniu treści, np.: mam wrażenie, że mniej „zostaje w głowie" lub można popaść w czytanie w biegu, bez skupienia. Czytanie Biblii zamieniało się wówczas $\mathrm{w}$ „powierzchowne” przeglądanie tekstu, „przeskakiwanie" przypominające nieco korzystanie z portali internetowych. Niewątpliwą wadą samego nośnika była jego uniwersalność i pospolitość, które generowały, wspominany wcześniej lęk przed negatywną opinią otoczenia, np.: że ekran świeci, ludzie myślą, że czytam smsy. Czynniki te uniemożliwiały tym samym dawanie świadectwa np.: Na pierwszy rzut oka trzymam $w$ ręku telefon - nie świadczę, że czytam Pismo św., gdyż tego nie widać. Respondentom towarzyszył też lęk przed_uproszczeniem i spowszednieniem lektury tekstu natchnionego, np.: Sa też sytuacje, w których papierowe wydanie Pisma św. jest najbardziej na miejscu (np. publiczne odczytywanie, spotkania wspólnot) $i$ w takich wypadkach wada aplikacji jest, że powoduje lenistwo i zastępowanie tradycyjnej wersji Pisma św.

3. Kolejną grupę ograniczeń wpływających na użytkowanie aplikacji można określić jako naruszenie sfery sacrum. Badani wskazywali - wspominane już - „spowszednienie” telefonu jako wykorzystywanego na co dzień nośnika różnych treści, np.: Spłyca trochę nasze podejście do Słowa Bożego, że nie traktujemy Go z należna czcia. Na przeszkodzie stała tu wielofunkcyjność telefonu: może za mało celebruje, kontempluje to Słowo przez to, że $w$ tym samym telefonie pisze smsy, korzystam z Facebooka, $i$ trudno jest mi rozdzielić ten przedmiot od sacrum Pisma św. Zaznaczano również (o czym pisałyśmy wcześniej), że telefon jako czytnik naruszał majestat, sacrum niektórych miejsc, np. $W$ wielu miejscach jednak nie przystoi używać telefonu, a więc i używać tej aplikacji.

4. Użytkownicy tradycjonaliści zwracali uwagę na trudność odzwyczajenia się od tradycyjnej formy kodeksu. Respondentom przeszkadzał zbyt nowoczesny, elektroniczny charakter nośnika, np.: Brak obcowania z pismem drukowanym - brakuje po prostu fizycznego kontak- 
tu ze Słowem. Wynikało to ze względów praktycznych i przyzwyczajeń, np. książka to jednak książka. można po niej pisać, podkreślać do woli $i$ kolorować, a tak mam $w$ zwyczaju. Telefon to nie to samo! Tradycyjny kodeks darzono dużym sentymentem np. Papier jest dla mnie nadal ważniejszy niż wersje elektroniczne. Jest bardziej „dostojny” lub mam większy respekt do tradycyjnych ksiażek $i$ wydaje mi się, że Słowo wydrukowane bardziej do mnie przemawia. Niektórzy respondenci wskazujący, że wersja elektroniczna sprzyja rozproszeniu, podkreślali jednak, że może to być kwestia przyzwyczajenia. Wydaje się więc, że część problemów wynikała z przywiązania do psychofizycznego procesu tradycyjnego czytania, np.: jako wzrokowiec kojarze czasem, że np. szukam czegoś co było na lewej stronie $w$ prawej kolumnie, na górze - $w$ aplikacji tym tropem nie pójdę.

\section{TRADYCYJNY KODEKS A APLIKACJA}

Podczas badania zachowań odbiorczych użytkowników wersji mobilnej, interesujące wydało się sprawdzenie, czy czytelnicy Biblii na telefon posiadają i czytają inne formy Pisma św. Okazało się, że prawie wszyscy mieli w domu tradycyjną Biblię papierową (99\%), przy czym swoich zwolenników miała też (popularna jeszcze przed erą smartfonów) wersja online na komputer (35,3\%). Posiadacze formy drukowanej, opisywali też miejsca/okoliczności jej lektury. Z jednej strony wskazywano bardzo podobne sytuacje jak w przypadku aplikacji: indywidualna lektura kontemplacyjna, wspólnotowe czytania rodzinne (celebrowanie świątecznych chwil). Często wymieniano też - rzadziej wspominaną przy wersji mobilnej - wspólnotową lekturę podczas spotkań religijnych np. w czasie rekolekcji, seminariów, mszy św. Wszystkie opisywane okoliczności sięgania po tradycyjny kodeks dotyczyły jednak miejsc i sytuacji stacjonarnych, natomiast prawie w ogóle nie wskazywano na dynamiczne, mobilne, a zwłaszcza niespodziewane okoliczności w jakich sięgano po aplikację na telefon (np. czytanie w podróży czy w miejscach oczekiwania). Papierowy kodeks zdecydowanie nie sprzyjał przypadkowej, nieoczekiwanej, sytuacyjnej lekturze Pisma św. 


\section{KOMUNIKOWANIE SIĘ TWÓRCY APLIKACJI I JEJ UŻYTKOWNIKÓW}

Zjawiskiem nowym, nie spotykanym dotychczas przy pracy nad edycjami papierowymi była również internetowa komunikacja pomiędzy twórcą aplikacji a jej użytkownikami. $\mathrm{Na}$ analizowanych stronach internetowych zamieszczano nie tylko aktualności, ale też propozycje współedycji ze strony administratora oraz komentarze i reakcje internautów.

Podawano zatem aktualne informacje na temat stanu a plika cji czyli liczbę pobrań, zapowiedzi kolejnych aktualizacji, np.:

W tym roku szykuje się bardzo duża aktualizacja. Na razie za dużo nie chcę mówić. Proszę o modlitwę. Jeśli wszystko się uda, będziecie mogli jeszcze więcej czerpać i zbliżać się do Boga dzięki naszej aplikacji!! Z Bogiem!:)

Na bieżąco wprowadzano uwagi o zmianie konkretnych elementów aplikacji, zwłaszcza grafiki lub nawigacji, np.: Zakładki: dodano przycisk „Kopiuj" oraz informowano o zainstalowaniu nowych wersji i ich zawartości, np.

Kochani (-) jak na pewno zauważyliście od tygodnia dostępna jest aktualizacja aplikacji na telefony $z$ androidem, a w niej: owoc prawie pótrocznej pracy: kompletnie nowa aplikacja Pismo Święte PL! J Jest szybciej, płynniej, wygodniej i mam nadzieję bezbłędnie. Wszystkie źródła zostały przygotowane od nowa, uzupetnione braki i błędne linki. Pobieranie informacji o Świętym $z$ dnia oraz komentarzu do czytań $z$ dnia. Brakujace wezwanie $w$ brewiarzu oraz wcięcia $w$ psalmach.

Ważnym elementem współpracy między twórcą i odbiorcami były zamieszczane propozycje współedycji. Przemysław Bierut zwracał się więc do internautów z prośbą o opinie lub konsultacje, np.: jeśli ktoś $z$ Was jest grafikiem i chciałby poświęcić chwile na pomoc w rozwoju aplikacji, to proszę o kontakt:) Administrator prosił też o reakcję zwrotną, czyli pobranie nowych wersji, ich ocenę i zgłaszanie uwag. Informował o zauważonych błędach, szybko reagował na zgłoszenia i przeprowadzał korekty, np. wkradł się błąd w uruchamianiu na niektórych urządzeniach. Dziękuję za szybka reakcję! Poprawiona aplikacja za chwile będzie do pobrania@; oraz zamieszczał komunikaty świadczące o permanentnej gotowości do pomocy, np.: W razie jakichkolwiek problemów lub uwag, jestem do dyspozycji:) 
Reakcje użytkowników, ich komentarze skierowane do administratora i do siebie nawzajem były szczególnie ważnym etapem na drodze współedycji aplikacji mobilnej. Internauci_wyrażali swoje uznanie dla kolejnych wersji, np.: Fantastyczny layout nowej wersji aplikacji! Bardzo dobrze wyglada i jest łatwiejszy w nawigacji. Pięknie zrobione, dzięki! lub wypowiadali się negatywnie na temat nowych rozwiązań, np.: Dlaczego zmieniliście layout? Poprzedni był zdecydowanie lepszy!!! Teraz ma brzydki, smutny kolor a ikony na stronie startowej sq dużo mniejsze. Teraz ikonka aplikacji wyglada naprawde stabo.

Aktywnie zgłaszano błędy, proponowano odmienne warianty grafiki, kolejne możliwości nawigacji, np.:

Nie wiem co planujecie $w$ aktualizacji, ale ja potrzebowałbym czegoś $w$ zakładkach. Mam ich dużo i potrzebowałbym je pogrupować, opisać, skatalogować. A chętnie i zapisać do pliku, żeby przenieść na nowy telefon, tablet;

lub przedstawiano propozycje dodania nowych tekstów, np.:

Moge zasugerować, aby do modlitw dodać kompletę, która jest stała częścia brewiarza (na każdy dzień tygodnia). Co umożliwi korzystanie z tej opcji bez potrzeby taczenia sie $z$ internetem.

Ciekawym zjawiskiem towarzyszącym komunikacji internetowej było stworzenie przez użytkowników swego rodzaju wspólnoty w sieci. Korzystający z wersji mobilnej zadawali sobie nawzajem różne pytania, np.: Kto mi podpowie, jak otworzyć brewiarz?; dopytywali i popierali się nawzajem, np.: Przyłaczam się do pytania; a także odpowiadali na pytania, zanim administrator zdążył zareagować np.: Aktualizacja czeka na certyfikacje Microsoft. Pojawi się lada moment. Niekiedy wypowiedź w sieci bywała okazją do nawiązania sympatycznej konwersacji, np. gdy jeden z użytkowników forum napisał: Dziękuję! Nie wyobrażam sobie śpiewania psalmów, Pisma św. w podróżach i podręcznego modlitewnika bez twojej apki! Organista jednej z podwileńskich parafji (-); reakcja innego internauty brzmiała: A ja bardzo dziękuje za przypomnienie międzywojennej pisowni „parafi”. Jest $w$ tym coś naprawdę urzekającego. Nierzadko też formułowano wypowiedzi tak, by wywoływały radosne reakcje wśród 
innych użytkowników forum, np. Genialna! Jakby to ująt Samsung-life companion (:)

Analizując uwagi w kwestionariuszach i opinie na stronach, zwróciłyśmy też uwagę na charakter j ęzyka, jakim posługiwali się użytkownicy aplikacji. Zazwyczaj wyrażano swoje zdanie w dość poprawnej formie językowej, choć czasem zdarzały się błędy ortograficzne. Wiele osób w sposób otwarty i nieskrępowany formułowało swoje opinie na temat mobilnej wersji Biblii. Przeważały uwagi w formie zwięzłych (typowych dla komunikacji internetowej) komentarzy, jednak nie brakowało też opinii obszerniejszych, np.

Na co dzień czytam Pismo Święte $w$ wersji papierowej i rozważam Słowo Boże w nim zawarte. Jest to Stowo Boga i nie wyobrażam sobie życia chrześcijańskiego bez karmienia się nim. Biblia na telefon jest dla mnie uzupetnieniem wersji papierowej.

Niektóre wypowiedzi respondentów odzwierciedlały pełnię wrażeń i (pozytywnych bądź negatywnych) emocji podczas korzystania $\mathrm{z}$ aplikacji, np.

Nowy design aplikacji jest bardzo słaby!!! Było bardzo interesujaco i nowocześnie a jest.... smutno. Zieleń [tła - przyp. autorek] kojarzyła mi się $z$ odnowa, wzrastaniem, brazowy jest bardzo smutny. Kliknąem na aktualizacje i ... CZUJĘ SIĘ OSZUKANY!!!! Chce mieć stara wersje u siebie na telefonie - czy to możliwe?

Niekiedy opinie wyrażone były młodzieżowym językiem, slangiem np. super apka, super ankietka; must have lub Nie jest ciężka, więc nie musze jej „dygać”. Zdarzało się, że niektóre określenia pozostawały w dysharmonii do przedmiotu komentarzy, np.: Nie jest pioruńsko ciężkie, więc mogę zawsze przy sobie mieć Słowo Boże. Pojawiły się też uwagi bardzo dosadne, czego przykładem mogą być niezbyt wyszukane komplementy, jakimi obdarzano aplikację, przy czym ich egzemplifikację stanowić może jedynie określenie najłagodniejsze: zarąbista. Tego typu kolokwializmy, a nawet wulgaryzmy, mimo iż wyrażające akceptację, uznanie, tworzyły znaczny dysonans w odniesieniu do treści i charakteru omawianej lektury. 


\section{PODSUMOWANIE}

W dyskusji o przemieszczających się granicach współczesnej książki, Biblia umożliwia spojrzenie z szerszej perspektywy na zachodzące obecnie zmiany, jako na nieustanną drogę przez wieki w kierunku upowszechnienia i przybliżania tekstu czytelnikowi. Współcześnie, na poziomie odbiorcy, przełamywanie granic Księgi Ksiąg następuje w różnych obszarach: edytowania, nośnika, miejsca, okoliczności i słowa. W Biblii na telefon nastąpiło przekroczenie granicy (współ)edytowania tekstu, bowiem nigdy wcześniej czytelnik/odbiorca nie miał takiego wpływu na postać zewnętrzną (szatę graficzną i funkcje użytkowe) Świętego Słowa jak obecnie. Współczesny, elektroniczny nośnik tekstu natchnionego jest jednocześnie narzędziem pracy, rozrywki, komunikacji, a przy tym równolegle stanowi medium Świętego Słowa. Te powszednie i niesakralne media, wykorzystywane w różnych wymiarach i okolicznościach, są wprowadzane na teren miejsc sakralnych. Z drugiej strony związany z użytkownikiem na stałe, a przy tym lekki i poręczny nośnik umożliwia dostęp do Pisma św. w każdym, nawet najbardziej nietypowym, ale też niesakralnym miejscu. Podobnie przekroczona została również granica dla okoliczności lektury tekstu natchnionego. Telefon używany w większości obszarów życia sprawia, że czytanie z niego (na nim?) Słowa staje się jedną z tych powszednich, codziennych, całkowicie zwyczajnych czynności. Jednakowoż daje to możliwość kontaktu ze Słowem nie tylko w starannie przygotowanych, celebrowanych i uroczystych okolicznościach ale też w „niekoniecznie uświęconych” sytuacjach, które pojawiają się spontanicznie i nieoczekiwanie w życiu ich uczestnika. I na koniec, słowo o Słowie wyrażane bywa językiem powszednim, slangowym, niekiedy dalekim od podniosłego i uświęconego. Jednocześnie znacząco rozszerzył się obszar dla rozprzestrzeniania świętego Słowa, a opinie o nim mogą być wyrażane w przestrzeni publicznej, powszechnej, właściwie globalnej. Umożliwia to tworzenie internetowej wspólnoty czytelników Pisma Świętego, wpisującej się w opinię Ireny Sochy na temat internetowych społeczności literackich i czytelniczych, które zdaniem badaczki - opierają swoje praktyki lekturowe we wspólnotowości, w bezpośrednim dialogu oraz sprzyjają kreatywności ${ }^{5}$.

${ }^{5}$ I. Socha, Zachowania lekturowe Polaków. Problemy i kategorie opisu czytel- 
Streszczenie. Przemiany technologiczne i cywilizacyjne zmieniają oblicze Biblii, a także sposoby korzystania z Księgi Ksiąg. W artykule przedstawiono zachowania czytelnicze użytkowników mobilnej wersji Biblii Tysiąclecia dostępnej za pośrednictwem aplikacji Pismo Święte Przemysława Bieruta. W tym celu przeprowadzono badania ankietowe wśród 105 aktywnie korzystających z aplikacji respondentów. Przedstawiono miejsca i okoliczności lektury, wady i zalety wersji mobilnej z perspektywy ich użytkowników oraz najczęściej wykorzystywane funkcje aplikacji. Porównano też okoliczności korzystania z aplikacji i tradycyjnego kodeksu. Zauważono, że na poziomie odbiorcy przełamywanie granic Księgi Ksiąg następuje w różnych obszarach: edytowania, nośnika, miejsca, okoliczności i słowa.

Słowa kluczowe: Biblia; Biblia Tysiąclecia; Pismo Święte; użytkownicy nowych technologii; zachowania czytelnicze; aplikacja mobilna

Abstract. Divinely Inspired Text Facing New Technologies. Mobile Application of the Holy Bible. Perspective of the receiver. Technological and civilizational changes have changed the appearance of the Holy Bible, as well as ways of using the Book of Books. The paper presents the reading behavior of users of the mobile version of the Bible of the Millennium available through the application of the Pismo Święte by Przemyslaw Bierut. For this purpose, a survey was conducted among 105 respondents actively using the application. The places and circumstances of the reading, the advantages and disadvantages of the mobile version from the perspective of its users and the most frequently used functions of the application have been presented. The circumstances of using the application and the traditional code have been compared. It has been noted that at the receiver level, breaking the boundaries of the Book of Books takes place in various areas, such as editing, media, place, circumstances and words.

Keywords: Holy Bible; Bible of the Millenium; users of new technologies; reading behavior; mobile application

\section{BIBLIOGRAFIA}

Bieńkowska, Barbara, Książka na przestrzeni dziejów, Centrum Edukacji Bibliotekarskiej, Informacyjnej i Dokumentacyjnej, Warszawa 2005.

Pietkiewicz, Rajmund, ks., Biblia Tysiąclecia w tradycji polskiego edytorstwa biblijnego [on-line]. Praca doktorska napisana pod kier. ks. prof. dr hab. Tomasza Hergesela, Wrocław 2004 Dostępny w www: http://digital.fides.org.pl/dlibra/docmetadata?id=730 (dostęp: 20.08.2015).

nictwa, w: Teoretyczne zagadnienia bibliologii i informatologii. Studia i Szkice, red. E. Kondek, Wydawnictwo Uniwersytetu Śląskiego, Katowice 2015, s. 11-31.. 
Pietkiewicz, Rajmund, ks., Biblia Polonorum. Tom V. Biblia Tysiaclecia (1965-2015), Wydawnictwo Pallottinum, Poznań 2015.

Pismo Święte. Oprogramowanie. Żyj słowem Boga na co dzień. Dostępny w www: https:// www.facebook.com/pismoswietepl/?fref=ts (dostęp: 10.03.2016).

Pismo Święte PL. Dostępny w www: http://www.pismo.swiete.pl/ (dostęp: 10.03.2016).

Socha, Irena, Zachowania lekturowe Polaków. Problemy i kategorie opisu czytelnictwa, w: Teoretyczne zagadnienia bibliologii i informatologii. Studia i szkice, red. E. Kondek, Wydawnictwo Uniwersytetu Śląskiego, Katowice 2015.

Wywiad przeprowadzony przez autorki artykułu z twórcą aplikacji Pismo Święte Przemysławem Bierutem w dn. 28.08.2015 r. (niepublikowany). 